\title{
LITERATURA Y PINTURA DECIMONÓNICAS: EL SIMBOLISMO DE "LA VISIÓN DE FRAY MARTÍN"
}

\author{
por Gerardo Pérez Calero
}

Se exponen en el presente trabajo las conexiones artísticas existentes entre Literatura y Pintura que en la centuria decimonona tienen aún más concomitancias en la tendencia simbolista del último cuarto del siglo.

Se analiza el caso particularmente interesante de la obra "La visión de Fray Martín" por sus valores literarios y plásticos, vista a través de la forma de expresar de un poeta (Gaspar Núñez de Arce) y de un pintor (José Jiménez Aranda), casi rigurosos coetáneos y por tanto con parecidas inquietudes estéticas que llevan al campo del simbolismo.

The present article outlines the artistic connections between literature and painting, which are even more closely linked by the symbolist trend in the last quarter of the 19th century.

The case of the work "The vision of Fray Martín», particularly interesting for its literary and plastic values, is analysed, as seen through the form of expression of a poet (Gaspar Núñez de Arce) and a painter (José Jiménez Aranda), almost exact peers and therefore sharing similar aesthetic concerns, which draw them to the field of symbolism.

La relación Literatura y Artes Plásticas constituye una constante de la creación contemporánea, más intensa cuando en la obra lo formal va cediendo paso al contenido, a los mensajes que la misma aporta. $\mathrm{O}$ bien uno depende del oro. Poco a poco los aspectos físicos del objeto artístico constituyen un mero convencionalismo sometido a veces a una simple apariencia. También en ocasiones, aún resaltando los aspectos extemos de la obra, el artista los aprovecha para profundizar en el contenido de la misma.

Lo dicho se hace más evidente en España en el último cuarto del siglo XIX, momento en el que la sociedad comienza a acusar los síntomas del cansancio 
tecnológico que la revolución industrial traía consigo desde algunas décadas antes y cuyo reflejo en las artes -literarias o plásticas- se concretan en una serie de tendencias - para algunos "ismos"-. Una de ellas es el Simbolismo. Actitud creadora caracterizada por el aprovechamiento de la apariencia de la obra en beneficio de una intencionalidad abstracta, no real, en ocasiones incluso difícil de entender pero llena de motivaciones. Su esencia romántica puede justificarse en España por el eco aún vigoroso del espíritu neorromántico fortuniano, así como por el sustrato barroco, nunca desaparecido y sempiterno presente en determinadas escuelas artísticas hispanas.

Las anteriores consideraciones nos introducen en el estudio de una interesante obra simbolista: "La visión de Fray Martín", escrita en 1880 por el vallisoletano Gaspar Núñez de Arce (1834-1903) e ilustrada ese mismo año y el siguiente en Sevilla por su casi riguroso coetáneo, el pintor hispalense José Jiménez Aranda (1837-1903) '. Obra, a nuestro entender, de interés para la comprensión no sólo de la tendencia simbolista en España sino también del enclave estético que supone para nosotros fecha tan significativa: a un cuarto de siglo del inicio de la pintura de historia; a sólo seis años de la Restauración monárquica y la muerte en Roma del pintor Mariano Fortuny y de la eclosión del Impresionismo en París, y a sólo algo más de tres lustros vista del 98.

La obra que estudiamos es fruto de la perfecta colaboración entre escritor y artista plástico: el uno ejecutando tres cantos poéticos y el pintor otras tantas ilustraciones dibujadas a la "gouache" de $50 \times 32 \mathrm{~cm}$. cuyos originales se encuentran en una colección particular madrileña ${ }^{2}$. Esta identificación literaturapintura la hacen suya los autores con su propio estilo, producto sin duda de la estética propia de la generación que vive la crisis del Romanticismo y el triunfo del Realismo. Mas su esencia es postromántica por lo que hace al uso frecuente de elementos retóricos, efectistas e incluso patéticos. Ambos artistas, al mismo tiempo, pretenden recoger a través de imágenes simbolistas atemporales y fantásticas su preocupación por los problemas morales contemporáneos fruto sin duda del cambio social a que hacíamos referencia al principio.

"La visión de Fray Martín" tiene como objeto, según su propio autor literario, representar mediante "los vivos colores de la fantasía las vacilaciones, incertidumbres y terrores que debieron conmover el espíritu del impetuoso agustino Martín Lutero antes de que se decidiese a quebrantar los vínculos de la obedien-

1. Tuvimos ocasión de ocupamos sucintamente de esta obra en anteriores trabajos: José Jiménez Aranda. Col. "Arte Hispalense", n.. 29, Sevilla, 1982, p. 33 y 135 a 141; "El Simbolismo en la Pintura sevillana (1880-1938)", "Laboratorio de Arte", n.o 2, Sevilla, 1989, pág. 185 y 186.

2. Seguimos para nuestro estudio la versión publicada en 1909 por la madrileña imprenta Artística de José Blass y Cía., editada por los herederos del pintor sevillano y con autorización del propietario de "La visión de Fray Martín". 
cia, a declararse en herética rebeldía contra Roma y a trastornar la paz del mundo cristiano".

Al propio tiempo la obra -como también señala Núñez de Arce- es fruto de la inspiración que sobre él ha experimentado la contemplación de la Historia de este extraordinario acontecimiento, "al cual debe en gran parte nuestra generación el estado de inquietud en que vive". Al mismo tiempo también, añade, ha sido escrito como "un desahogo de mi corazón y de mi espíritu". Tampoco tiene una intencionalidad crítica, sino "un estudio puramente psicológico en la esfera del arte". Sin pretensión de juzgar ni acriminar, ni absolver. Se limita a "pintar las angustias de un alma en los momentos supremos de su transfiguración y de su caída. Los silenciosos combates de la fe y de la duda en lo más hondo de la conciencia humana".

Hechas las anteriores consideraciones por parte del propio escritor, entraremos en el análisis poético y pictórico de la obra atendiendo a sus peculiaridades simbolistas.

En el primer canto se describe pormenorizadamente la escenificación en la que, tras una ambientación previa de circunstancias temporales (Una noche "destemplada y triste del invierno aterido" y "a la hora de los maitines") y espaciales (En el viejo templo de padres agustinos) de las estrofas I y II cargadas de simbolismos siniestros ("la nieve silenciosa, descendiendo del alto cielo en abundantes copos como sudario fúnebre cubría la amortecida tierra", o "Lúgubre tañidos de la campana que con voz sonora desde la torre a la oración llamando, en sus vibrantes notas contenía todo el siniestro horror de aquella noche, negra y glacial como el ingrato olvido de la mujer amada"), el protagonista (Martín Lutero) tras recorrer determinadas estancias del convento, ocupa su asiento en la esbelta y tallada sillería del coro. Después, el poeta pasa a describir con toda suerte de alegorías, símbolos y fantasías literarias -difíciles de representar en pintura-el momento solemne en que:

"El órgano, hasta entonces vacilante, rompió, como ruidosa catarata, en raudales de mística armonía, y cual aves que salen de sus nidos al llamarlas el sol, ágiles notas en tropel la alta bóveda inundaron, ya graves, ya sumisas, ya imponentes. Después el rezo comenzó" 3 .

3. Estrofa VI. 
En las dos siguientes estrofas el autor se recrea en hacer comprensibles, mediante palabras, los efectos espirituales de la música y del cántico coral:-

"¿Quién oye

sin alterarse el recogido acento, el unísono cántico que elevan

a Dios las almas puras, olvidadas

del mundo y de las locas vanidades?

¿Quién no siente de lágrimas henchidos los ojos? ¿Quién no tiembla y se estremece cuando en la nave colosal retumba, con la terrible majestad del trueno, ese coro magnífico y sublime, mitad imprecación, mitad sollozo, en que parece que palpita y llora abrazado el dolor a la esperanza, como un esposo al cuerpo inanimado de la mujer a quien amó rendido?

Los salmos de David son como el viento, que apacible y sutil el campo orea, grana la mies y en melodiosas arpas los corpulentos árboles convierte. Mas luego, fiero y desatado, troncha los más robustos troncos, las campiñas y los poblados tala, hincha los mares revolviendo las olas, y el espacio con sus bramidos espantosos llena. También el canto del salterio enjuga el lloro acerbo, vierte en las heridas consoladores bálsamos, conforta al débil, da vigor al oprimido y al enfermo salud. Mas jay si estalla en sus tremendas notas el enojo! ¡Ay si el céfiro blando se transforma en huracán desenfrenado! Entonces abate a los soberbios, aniquila la maldad orgullosa y hasta avienta el olvidado polvo de las tumbas. 


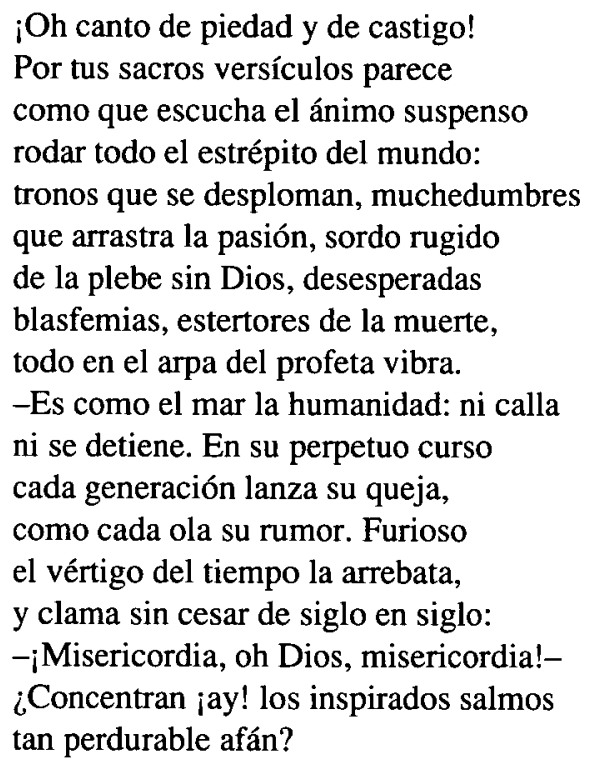

A continuación (estrofa IX) el poeta describe, recurriendo de nuevo a intencionados simbolismos, la turbulenta agitación espiritual que poco a poco va enbargando a Lutero provocada por la acción "impía, tentadora y rebelde" de Luzbel, en medio de la cual surge la duda, a la que describe como "la ansiedad suprema del náufrago infeliz arrebatado por las rugientes y encrespadas olas".

A esta agitación espiritual del fraile contribuyen sensiblemente la acción de "los bíblicos lamentos, los dolientes ayes y los versículos sublimes que del coro monástico surgían, diríase que en raudas espirales que iban a hundirse en la profunda niebla, espesándola más". Añadiendo:

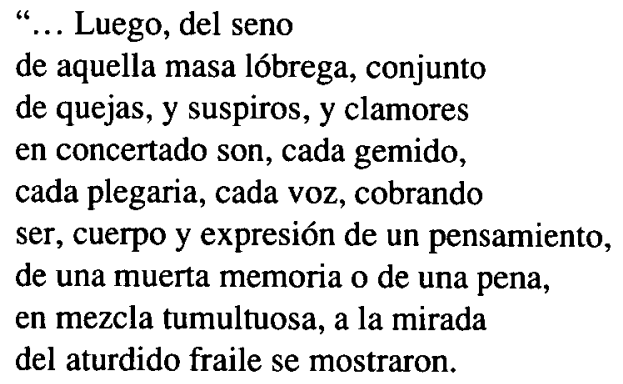

La estrofa $\mathrm{X}$ da paso a una narración fantástica en la que se hacen presentes, por medio de numerosas alusiones simbólicas, una serie de elementos y seres 
siniestros que en "vertiginosa danza, en incesante giro, en continuo movimiento, como nocturnas aves" revivieron en Lutero "las recónditas ansias, las pasiones dormidas, los recuerdos inoportunos y cuantos vicios escondidos yacen en lo oscuro del alma, tomando caprichosas formas: la gula, la codicia, el rencor, la hipocresía, la pálida envidia, el vil recelo, la iracunda ambición, el hondo hastío".

Ante tales visiones, en la siguiente composición poética (estrofa XI) el autor nos muestra a un Lutero "jadeante y confuso" que, ante ellas, clava su "deslumbrante vista" en el suelo apartándola de tan "horripilante cuadro que heló su sangre y su sudor de muerte cubrió sus miembros rígidos e hirió su trastornada fantasía".

Mas, nueva visión se presenta ante el protagonista que se nos muestra por el poeta cual caballero medieval o barroco:
"Fríos y descarnados esqueletos recién salidos de sus tumbas, mudos, inmóviles y absortos, con los brazos tendidos, en la iglesia se agolpaban de espaldas al altar, mirando al coro, $\mathrm{y}$ animaba sus mustiales calaveras mueca infernal, incomprensible, oscura, ¿Lloraban? ¿Se reían? ¿Aquel gesto era de escarnio o de dolor? Vedado está el misterio a la razón del hombre. ¿Quién interroga a los sepulcros? Nadie sabrá jamás lo que en su abismo encierran. ¿Es la vida? ¿Es la muerte? ¿Es el principio? ¿Es el fin? ¿Es la nada?... ¡Eterno enigma! ¡Este es el mundo! El vértigo en su altura; abajo, la bullente podredumbre, y en el mar, la sombra.

La estrofa XII nos presenta a la tentación. No con su habitual apariencia simbólica fea y horripilante sino -como dice Núñez de Arce- "insinuante, hermosa e irresistible" ${ }^{4}$ :

“... y alzóse al punto

de las tinieblas virginal figura

4. Nota 3.a de la edición antes mencionada en nota 2. 
hermosa y fulgurante, pero triste. Larga, enlutada túnica cubría sus púdicos contornos, cual celaje que vela el blanco disco de la luna sin amenguar su resplandor; sus ojos no lanzaban sus ráfagas de fuego que en la núbil pupila amor enciende, pero brillaban transparentes, puros, como los astros en tranquila noche de caluroso estío; su ondulante y negra cabellera, en destrenzadas hebras por la ancha espalda descendiendo, con doble encanto resaltar hacía la grave y melancólica hermosura de la celeste aparición, envuelta . en una claridad como de aurora".

Mas, esta alegoría de la tentación aparentemente dichosa, diríase perfecta, la tilda el poeta al propio tiempo de infeliz, pues como dice al final de esta estrofa:
"Pintábase en su faz meditabunda y pálida el dolor; ese infinito dolor que azora el corazón humano cuando busca y no encuentra, cuando mira y no ve, cuando lucha y desfallece".

La tentación hace presa en Lutero. Tal como se nos describe en la siguiente estrofa (XIII) en una composición cargada de efectos visuales dignos de la correspondiente interpretación pictórica, como luego se verá:
"Cruzando leve el círculo movible de seres impalpables, que llenaban la bóveda espaciosa, la serena visión, rompiendo el aire, entró en el coro, y en el respaldo del sitial labrado en que convulso el fraile padecía tan tremendas angustias, silenciosa apoyó dulcemente el blando seno. Vióla el monje llegar, cerró los ojos, y al través de los párpados, más viva 
la imagen percibió; sintió unos brazos

que le estrechaban afanosos; luego

un ósculo glacial, que a un tiempo mismo

le helaba el corazón y el encendía

la mente; luego penetróle el alma

una voz regalada y cadenciosa, como suspiro de amorosa virgen;

voz que, temblando, le decía:-Deja

que te abrace otra vez. ¿Quién este nudo

podrá ya desatar? ¡Ven! Te he besado

y ya eres mío, ipara siempre mío!-

Este primer canto tiene su culminación en la estrofa XIV en la que, al propio tiempo que el coro de frailes entona "pausadas preces" acompañado del "órgano en crescendo solemne y grave", la tentación acosa con sus halagos al fraile:

"Si en seguirme consientes, pide, y mi amor te colmará fecundo de dones y presentes; tuyos serán los términos del mundo $\mathrm{y}$ te daré por heredad las gentes".

Ante tal acoso, aparece por fin ante Lutero la figura simbólica de la Duda:

"¿Vacilas? Ten aliento, y no el torpe recelo te confanda; eleva el pensamiento, y libre como el pájaro en el viento, quebranta tu cadena y tu coyunda.

Rígido, incierto, atormentado acaso por ocultos deseos, hasta entonces nunca sentidos, $y$ que el leve acento de la visión en su interior movía, volvióse el fraile, y preguntó azorado:

-¿Quién eres? ¿Qué pretendes? ¿Por qué alteras mi oración y mi paz? - ¿No me conoces?le respondió, atrayéndole afanosa: - Yo soy, mírame bien, algo que vive y algo que ha muerto en tí. Soy una llama 
que surge de improviso en el abismo de tu inquieta razón. ¡Yo soy la Duda! Al oír esto, irguióse el sacerdote, y acometido de mortal desmayo, quiso escapar de allí, más vino a tierra como la encina rota por el rayo".

Por su parte, el pintor Jiménez Aranda en la lámina que ilustra este primer canto ejecuta una representación alusiva a la visión de Lutero; es decir cuando éste -como se ha visto en la versión literaria- se encuentra en el coro ocupando su asiento junto a los demás frailes y es abrazado por la hermosa figura de aspecto aparentemente angelical que representa la tentación, al propio tiempo que revolotea por la parte superior de la estancia un grupo de figuras femeninas semidesnudas que representan toda suerte de pecados, mientras numerosas calaveras con actitudes harto expresivas parecen salir de sus tumbas por la parte inferior de la representación con intención de dirigirse hacia donde se encuentra Lutero.

Iconográficamente la obra del pintor sevillano está concebida al modo de las representaciones barrocas españolas del siglo XVII cuya composición en perspectiva oblicua recuerda -como escribíamos en otra ocasión s- la que usa el pintor madrileño Claudio Coello (1642-1693) para concebir su cuadro La adoración de la Sagrada Forma por parte de Carlos II (Sacristía de El Escorial). Lo cual hasta cierto punto es justificable si se tiene en cuenta el ambiente en el que se había formado y en el que vivía el artista hispalense; su viaje a Roma y en consecuencia su estilo rico en elementos expresivistas y alusiones simbólicas, a lo que contribuyen muy especialmente los efectos lumínicos que crean un aparente dramatismo muy del gusto del Seiscientos sevillano y madrileño, los cuales al propio tiempo establecen condiciones teatrales en la representación.

El canto segundo comienza en su primera estrofa con la narración poética en la que aparecen los frailes recogiendo el cuerpo inerme de Lutero "lívido, mustio, cual si el soplo helado de la implacable muerte hubiese roto su frágil existencia". Después (estrofas I a IV) el poeta aprovecha la situación creada por su propio argumento para entrar a expresar en tono solemne la lucha humana entre el cuerpo y el alma y la dependencia entre ambos.

Ya en la estrofa siguiente, Núñez de Arce, movido por lo fantástico, describe el momento sublime en que el "temeroso espíritu del fraile" es conducido por la "visión doliente" a una inmensa altura en donde se halla una abrupta roca que parecía apoyada en "las entrañas del infierno" y cuya cima era inaccesible. Allí,

5. Véase nuestro libro citado en nota 1, pág. 136. 
fuera de referencias espaciales y temporales se presenta ante Lutero otra visión. Esta vez, si cabe, más fantástica: la humanidad (el poeta habla del "linaje de Adán") en "marcha fatigosa" por los males que tiene que superar (el poeta los expresa simbólicamente como "agudas zarzas"; "angostos precipicios"; "tristes desfiladeros"; "páramos incultos", "sin un arroyo limpio y sereno en que templar la sed y sin un abrigo donde buscar reposo") enfrascada en "horrendas luchas, impensadas catástrofes y fieras venganzas" que la "diezmaban de continuo" se hundía en la vorágine del tiempo. "Leyes, usos, monumentos y gloria, hasta los mismos dioses, temblando de pavor, rodaban al fondo de la sima".

En este ambiente de caos contemplado por Lutero, en el que el tiempo no tenía sentido y todo era efímero, sólo prevalecía el Verbo, "la palabra humana que flotaba sobre el mundo, el inmenso espíritu de Dios". Sólo Él "sobrenadando, transmitía la herencia, el pensamiento y la memoria del pueblo muerto al pueblo que llegaba" (estrofa IX).

Después, el poeta enriquece esta visión presente ante el fraile reformador, ahora timorato por la presencia apocalíptica de la muerte:

"Pálida, sigilosa, descargando
certeros golpes por doquier la muerte
en pugna eterna con la vida, el aire
envenenaba con su helado aliento,
y en pos, blandiendo sus cortantes hoces,
iban sus hijas, la ambición, la peste,
el hambre y la discordia. Sin reposo
sobre la humana especie revolaban,
como bandas de voraces buitres
que acuden al festín de la pelea".

Frente a la muerte, una de las figuras simbólicas más logradas por el poeta, éste hace aparecer ante Lutero a la Vida, con un espíritu de aparente contradicción romántica, a la que dedica un cántico solemne de alabanza, lleno al mismo tiempo de valores simbólicos:

“... y perseguían con perenne furia la vida hasta en el átomo impalpable.

Pero extremaban su rencor en vano; pues cual simiente que en el fértil surco cae y germina, cada ser vencido en la revuelta lid, de nuestros seres origen era, y parecida a Anteo, 


\begin{abstract}
la disuelta materia renacía
al tocar la tierra, más pujante, más rica, más espléndida, más varia. ¡Oh generosa vida, que conviertes hasta el sepulcro en cuna, y sólo entregas a la insaciable destrucción, la forma perecedera y ruin! ¡Mil veces salve! ¡Mil veces salve! Tu ánfora divina nunca se agota. Pueblas el espacio de incalculables mundos, y los mundos de innumerables seres que revisten las más diversas formas; tú fecundas lo pequeño y lo grande, lo finito y lo infinito, el átomo y el cielo. ¡Vida, aliento de Dios, mil veces salve!
\end{abstract}

En las siguientes estrofas de este mismo canto segundo, el poeta sigue ofreciendo los variados aspectos que se presentan ante Lutero "desde la enhiesta y solitaria roca"; ahora son (estrofa XI) "extrañas gentes de distinto color, de opuestos ritos y múltiples costumbres" que "afluían al áspero sendero". Todos aspirando a lograr el cielo. De este modo continúa la fantástica narración:

\author{
"Allí el etiope, \\ el escita, el que acampa en los desiertos \\ del África recóndita, el que bebe \\ las turbias aguas del sagrado Ganges, \\ el indio errante sin hogar ni patria, \\ que al través de las selvas primitivas \\ su ley, su Dios y hasta sus muertos lleva, \\ el que milita en la escogida hueste \\ de Cristo, el que le niega o le desdora \\ y da su vida en holocausto impuro \\ al triunfal carro de mentidos dioses, \\ por el error vencido o por el miedo, \\ en la escabrosa senda se agolpaban".
}

La visión -“el cuadro", según el poeta- iba acrecentándose en sublimidad; así, en las siguientes estrofas (XII a la XVII) muéstrase, como si de una narra- 
ción dantesca se tratase, varios niveles: "por el fondo de la cuesta fragosa de las brumas iban aglomerándose, las razas inferiores marchando con incierto paso y cobarde indecisión". En este oscuro lugar dominaban "las torvas pasiones", "los bestiales apetitos", "los bárbaros cultos y los monstruos horribles creados por la ignorancia".

Después, tras este ínfimo nivel, más próximo ya a la luz de la superficie, aparecen otros pueblos cuyo juicio se agigantaba, "sacudiendo el yugo del instinto brutal". Con un simbolismo bíblico resume Núñez de Arce esta estrofa: "A Esaú velludo reemplazó Jacob".

Aparecen también en esta visión ante Lutero los pueblos identificados como de Europa, delante de la cual se muestra la sagrada Roma con su poder supremo ante el que se doblegaban "las almas y los cuerpos, los muertos y los vivos, el pensamiento y la esperanza". Mas también este poder, al tiempo que le daba "apóstoles y esclavos, fervientes defensores, verdugos, miedo, el corazón culpado o receloso". Hasta " ¡El cielo, cuyas puertas de diamante se abren o cierran a su voz!".

La visión apocalíptica llega a su culmen en la estrofa XV en que se presen$\tan :$

“... rojos vapores

de sangre hacia la cúspide ascendían, y en el aire espesándose, tomaban de alado aspecto la terrible forma. La bestia apocalíptica que en Patmos vio el inspirado Juan, la bestia enorme de hirsutos pies, de coronadas astas y bocados de blasfemia, sobre Roma se dilataba como nube ardiente".

Ante tan horrible visión, la conciencia de Lutero por boca del poeta, se pregunta angustiada:

“¿Dónde estaba Jesús? En donde estaba

María, madre del dolor humano

y estrella de los mares procelosos?

¿En dónde estaba la verdad? ¿En dónde?

La Roma santa aparece en esta nefasta apariencia sometida a las siniestras fuerzas del mal, para cuya representación el poeta evoca los tiempos gloriosos del siglo XVI, reinando el Papa León X, simbolizado en esta versión poética por 
la escultura del Moisés de Miguel Ángel (versión de Zeus) o por una madonna de Rafael (inspirada en las Venus clásicas) ${ }^{6}$.

Al propio tiempo también se describe la presencia del "espectro del Papa Borja", quien:
“... con crispada mano
sacudiendo su túnica empapada
de hirviente sangre, y vio que cada gota
en lúgubre fantasma convertida,
iba aumentando la legión siniestra
de vengadoras víctimas que al monstruo
con sordos anatemas acosaban".

E igualmente presenta al Papa Julio II a quien ve del modo siguiente:
“... de áspero semblante
y mirada tenaz, que revestido
de milanesa cota y férreo casco, con belicoso ardor, en lid sañuda, rezaba y combatía, al propio tiempo
bendiciendo y matando con su espada".

Finalmente, de nuevo la Duda se hace visible, dilatándose:
“... cual nube
que el claro espacio de improviso invade, y de sus ojos desbordó la sombra como una inundación: fijó su triste y amorosa mirada en el confuso espíritu del monje, que la dura y estéril peña oraba prosternado, y un silencio mortal reinó en la altura.

La versión pictórica del aludido canto segundo nos presenta otra composición fantástica que evoca la estética manierista, esto es, cuadro vertical dividido en tres niveles en los que se presentan otras tantas imágenes literarias y cuya

6. Esta alusión al Quincuecento romano (y también florentino), así como el simbolismo con obras de Miguel Angel Buonarrotti y de Rafael de Urbino viene recogido, además, en las notas $5 .^{\mathrm{a}}$ y

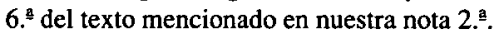


lectura corresponde de abajo arriba a los tres momentos mencionados por el poeta: en el primer nivel aparece la figura papal portentosa revestida con capa pluvial y tocada con la tiara en actitud de bendecir al pueblo que se mofa.

El segundo nivel muestra en el centro al Papa Borja sacudiéndose su túnica a la que pretenden asirse varias figuras varoniles desnudas. Más a la izquierda del espectador el pintor representa al Papa Julio cual caballero con coraza y casco blandiendo una espada junto a un fraile que porta la cruz pontifical.

Mas arriba, a la derecha, aparece la figura de Lutero acompañado por la Visión personificada como una hermosa joven de desnudos hombros que señala con el dedo índice de su mano diestra hacia el espectáculo que se ofrece ante los ojos del fraile reformador.

En la cumbre de la representación pictórica, Jiménez Aranda coloca en un espacio despejado de niebla y brumas la representación de la Roma eterna: la Basílica de San Pedro del Vaticano y el castel Sant'Angelo.

El pintor sevillano se identifica plenamente de nuevo con el poeta castellano en esta representación cargada de efectos fantásticos por su teatralidad a la que contribuye especialmente la iluminación claroscurista. Ha sabido recrear eficazmente mediante la imagen el difícil y abarrocado lenguaje poético de Núñez de Arce.

El canto tercero y último de "La visión de Fray Martín", el más breve, se ocupa de la lucha interna que en Lutero entablan -como dice el poeta- "la fe imperiosa y la razón rebelde".

La visión contempla ahora -recoge el propio autor literario en la primera estrofa- el cumplimiento de las santas profecías a las que dará lugar la actitud rebelde del protagonista de la obra, y en tono elegíaco da paso a una serie de narraciones simbólicas alusivas al hecho histórico cargado de connotaciones líricas.

En la tercera estrofa se narra simbólicamente la caída física de Lutero desde la alta cima en que se encontraba contemplando las consecuencias de sus desvaríos dogmáticos. El poeta describe con gran fuerza el hecho:

"De roca en roca, como alud que baja de inaccesible monte derrumbado, con ímpetu cayó, no conocido, hasta los bordes de la inmensa sombra que llenaba el abismo pavoroso bajo sus pies abiertos $;$ Oh perdurable y terrible caída, que recuerda la de Luzbel desvanecido!

En vano el monje en las cortantes grietas 
buscaba apoyo y contener quería su rápido descenso, como el ave que herida en el espacio y moribunda, con las últimas ansias aletea.

A la presión de su insegura mano los peñascos cediendo, con medroso estrépito tras él se desprendían..." alma:

Después, el poeta establece un paralelo simbólico entre la caída moral o del “... y el alma al par de las heridas peñas que arrancaba de cuajo la convulsa revolución del monte, desolada en la noche sin fin se sumergía".

y el derrumbamiento, aniquilación y caída sucesivos de las obras de arte relacionadas con la fe religiosa católica, así:

“... Los enormes fragmentos de la roca,
que a su paso saltaban, impelidos
por fuerza oculta en progresión creciente,
ante su vista atónita tomaban
fantásticos contornos, en el aire
cambiando sin cesar. Góticos templos,
labrados claustros, toscas esculturas,
altares y sepulcros, en ruidoso
remolino de escombros le seguían,
como si el orbe todo, desquiciado,
detrás del alma al precipicio fuera
llevado por el vértigo".

Estos últimos versículos son los que precisamente dan pie a Jiménez Aranda para representar su lámina tercera, ejecutada en Sevilla en 1881. En ella muestra, en medio de un escenario fantástico, la caída de Lutero desde la imponente altura en que se encontraba anteriormente. El pintor aprovecha las circunstancias del hecho para componer mediante una forzada perspectiva los efectos espectaculares de la acción llena de teatralidad; así, el fraile puede verse de arriba abajo intentando asirse a las numerosas piedras y fragmentos arquitectónicos que, como en un violento torbellino se precipitan hacia el fondo en donde sitúa el 
pintor el punto de fuga de la composición. Al propio tiempo la alegoría de la Duda en caída libre se precipita también al abismo, cual bruja voladora, con los brazos abiertos y con expresión terrible.

Poéticamente la obra de Núñez de Arce termina en la estrofa $V$ en tono dramático presentando a un Lutero abatido postrado en el lecho de su celda como si volviese de un espantoso sueño rodeado de sus compañeros frailes. El prior le anima y pide que de gracias a Dios por haberle apartado del "borde de la fosa", mas el fraile rebelde convencido de su misión protestante, le responde:

"¡Ya no soy lo que fui! Pesa en mis hombros la grosera cogulla, y me avergüenza mi antigua misión. ¡Rompo mis lazos! ¡Cobro mi libertad! ¡Nazco a la vida!

El prior reprende la actitud desafiante de Lutero mientras sus compañeros se apartan de él tachándole de loco. Mas Lutero responde al trémulo prior que desea "¡Vencer a Roma!", por lo que su superior le tacha de anatema.

$\mathrm{La}$ obra termina con tres rotundos versos que sintetizan el simbolismo literario de toda ella:

" Ya que indomable orgullo te desliga de nuestra santa fe, siglos y siglos la maldición del cielo te persiga!". 


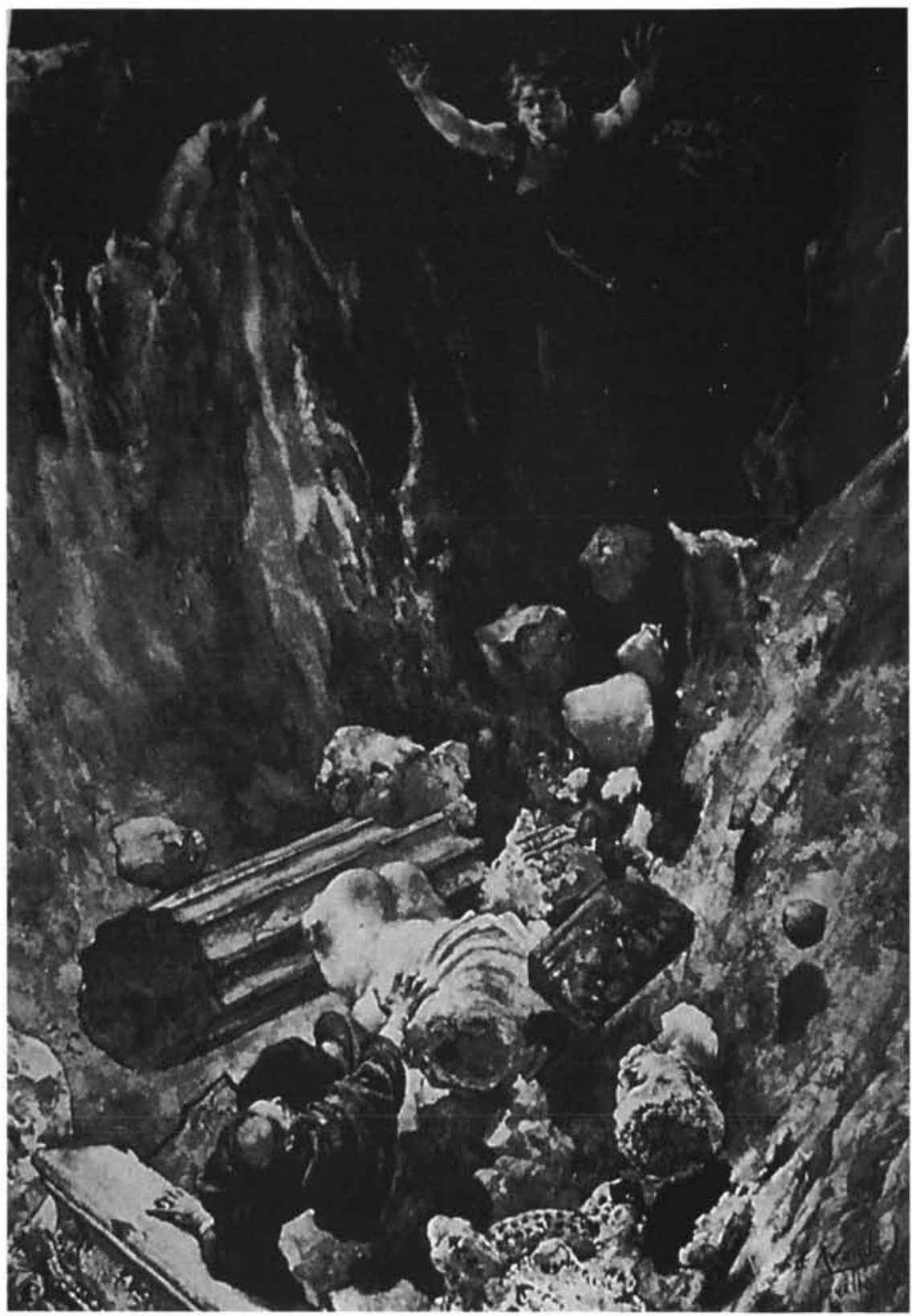

La visión de Fray Martín. Tríptico, dibujo a la gouache. 


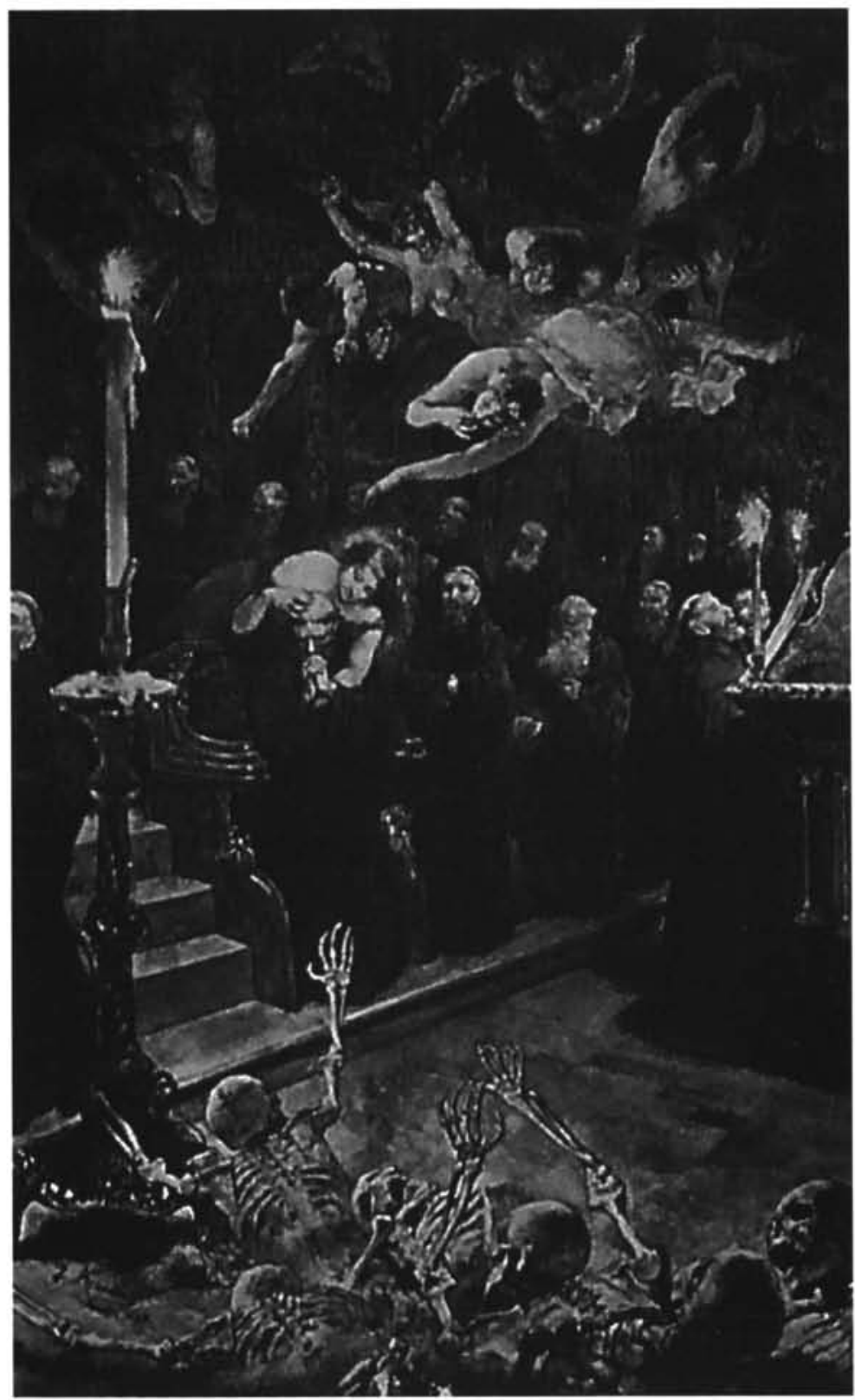

La visión de Fray Martín. Tríptico, dibujo a la gouache. 


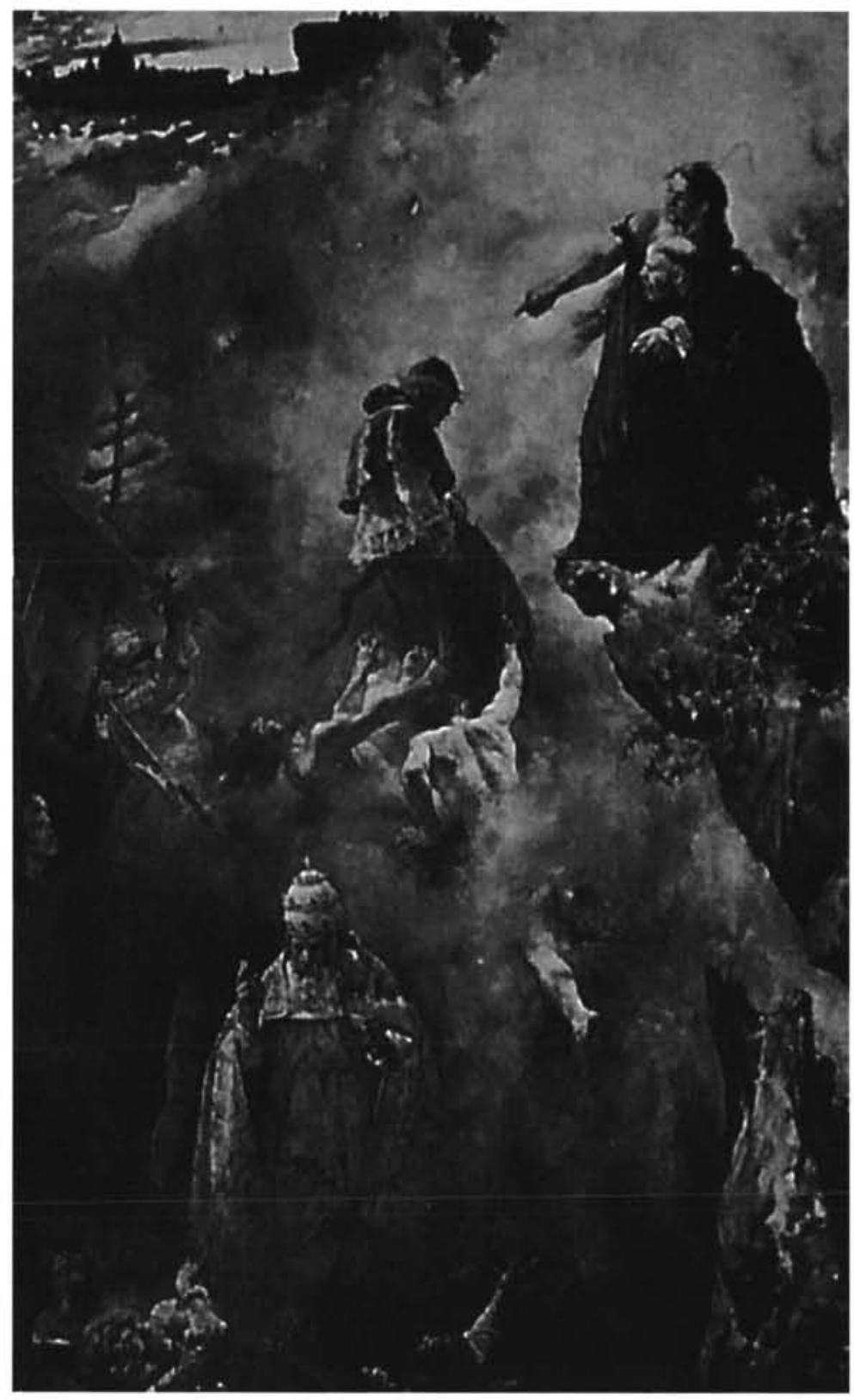

La visión de Fray Martín. Tríptico, dibujo a la gouache. 